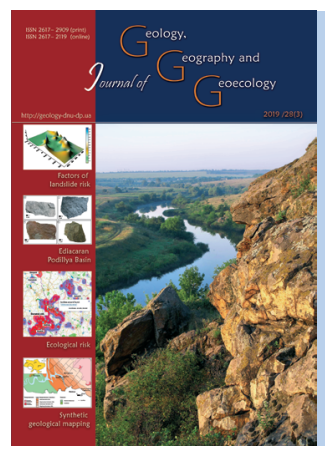

Journal of Geology.

ISSN 2617-2909 (print)

Geography and

Geoecology

ISSN 2617-2119 (online)

T. P. Mokritskaya, L.O. Nosova

Journal home page: geology-dnu-dp.ua

Journ.Geol.Geograph.

Geology,

28(3), 504-510.

doi: $10.15421 / 111946$

\title{
Forecasting suffusion deformation in dispersive soils
}

\author{
T.P. Mokrytskaya, L.O. Nosova \\ Oles Honchar Dnipro National University, Dnipro, Ukraine, mokritska@i.ua
}

Received: 08.06.2019

Received in revised form: 24.06 .2019

Accepted: 10.07.2019
Journ. Geol. Geograph. Geoecology, 28(3), 504-510.

the period of 12.02.2018 - 13.04.2018, a new soil structure experiencing certain changes while interacting with the flow. During ment was carried out at the SRI of Geology of Oles Honchar DNU; it is the continuation of the research dealing with experimental study of the dispersive soils as complex natural systems. To study suffusion process in loessial soils, analysis of microaggregate and granulometric composition of a sample of undisturbed structure of Dnipro loessial horizon taken in Tunelna ravine outcrop has been performed. The sample was studied in different states: natural and changed (due to long-term filtration) ones. Results of the use of innovative method to determine values of the function of particle distribution in terms of their mass and calculations of fractal dimension of the function basing upon the microaggregate analysis have made is possible to forecast values of porosity coefficient and volumetric deformation corresponding to the new quality standards of a complex system - dispersive soil in the state of complete microaggregate disturbance. Algorithm of the microaggregate composition analysis according to the methodology (Riashchenko, 2010) is in the fact that the sample experiences different methods of preparation - thus, evaluations of soil dispersivity are different. Basing upon the obtained results, values of microaggregate coefficient have been calculated, and data on the number of aggregates and initial particles have been taken. It has been determined that the basic size of the aggregates is $0.01-0.005 \mathrm{~mm}$; there is a fewer share of the aggregates of $0.05-0.01 \mathrm{~mm}$; and the fewest share of the aggregates is represented by fine fraction. That indicates the changes in microaggregate composition of soil due to the carrying out of fine fractions and the disturbance of larger aggregates. Calculations of the values of volumetric soil deformation due to long-term salt solution filtration emphasize the fact that within the zones of technogenic contamination, possible aggregate decay due to chemical effect will result in the formation of structure with denser particle packing, i.e. compaction. If loessial layers with the state changed due to salt solution filtration are subject to mechanical effect, drastic soil loosening and loss of soil stability may be observed.

Key words: suffusion, Dnipro loessial soil, fractal

\section{Прогнозування деформації суфозії в дисперсних грунтах}

\author{
Т.П. Мокрицька, Л.О. Носова
}

Дніпровський національний університет імені Олеся Гончара, Дніпро, Україна, mokritska@i.ua

Анотація. Суфозія - небезпечний геологічний процес, що супроводжується формуванням провалів, деформаціями будівель
і споруд. Прогноз суфозійних процесів представляє складну наукову проблему, так як потрібно спрогнозувати складний
процес формування нової структури грунту що зазнає змін при взаємодії з потоком. На протязі двох місяців з 12.02 .2018 р. по
13.04.2018 року зразок дніпровського лесового грунту був підвернутий фільтрації розчином соли у приладі Дарсі. Експеримент
виконувався в НДІ геології ДНУ імені О.Гончара та є подовженням наукового напряму - експериментального дослідження
дисперсних грунтів як складних природних систем. Для дослідження процесу суфозії в лесовому грунті був виконаний аналіз
мікроагрегатного та гранулометричного складу зразка непорушеної структури дніпровського лесового горизонту, що був
відібраний з відслонення у б. Тунельної. Зразок був досліджений у різних станах: у природньому та у зміненому в наслідок
тривалої фільтрації. За результатами застосування нового методу встановлення значень функції розподілу часток за їх масою,
розрахунків фрактальної розмірності функції на підставі мікроагрегатного аналізу доведена можливість прогнозу значень 
коефіцієнту пористості та об’ємної деформації які відповідають новому якісному стану складної системи - дисперсному грунту у стані повного порушення мікроагрегатів. Алгоритм досліджень мікроагрегатного складу за методикою (Riashchenko, 2010) полягає в тому, що до зразка застосовують різні засоби підготовки, завдяки чому оцінки дисперсності грунту є різними. На підставі отриманих результатів, були розраховані значення коефіцієнту мікроагрегатності, отримані данні про кількість агрегатів та первинних часток. Встановлено, що агрегати мають розмір в основному 0,01-0,005 мм, агрегаті розміром 0,050,01 мм присутні у меншої кількості та кількість агрегатів тонких фракцій найменша. Це вказує на зміни мікроагрегатного складу грунту внаслідок виносу дрібних фракцій та на порушення агрегатів більших за розміром. Розрахунки значень об’ємної деформації грунту внаслідок тривалої фільтрації розчином солей вказують на те, що у зонах техногенного забруднення можливий розпад мікроагрегатів внаслідок хімічного впливу призведе до формування структури з більш плитною упаковкою часток, до стискання. Якщо лесові горизонти зі зміненим станом внаслідок фільтрації сольового розчину будуть підвергнути механічному впливу можливим є розпушення грунтів, можливим є різке розпушення та втрата стійкості грунту.

Ключові слова: суфозія, дніпровський лесовий трунт, фрактал

Introduction. Development of the experimental studies of the dispersive soil properties is the basis for successful solution of investment problems in the process of construction, especially within the zones characterized by complex geological processes. Suffusion is not often analyzed in engineering and geological studies. Nevertheless, it is known that suffusion phenomena within the areas of the available loessial soils is widely occurred and connected with subsidental, landslide, and erosive developments. Special attention is paid to the consideration of the processes in soil medium with the signs of fractal. Thus, studies of the processes of turbulence (Jafari et al., 2019), percolation (Ziani, 2019), peculiarities of soil behaviour within the shear zone (Lu et al., 2018) are carried out on the basis of the fractal theory elements. Wang et al. (2015) applied calculations of fractal size to define regularities of spatial changes in the properties of loessial soils to implement innovative recultivation methods. Liu et al., 2013, determined the connection between fractal volumetric size of natural soil particles and amount of organic substance and argillaceous particles. Suffusion methods are developed on the basis of classic techniques (Khuzhaerov, 1994), (Nikiforov, 2000). Research by Gudehus, \& Touplikiotis, (2017) substantiates importance of the analysis of soils as natural fractals as for solving the problem of forecasting "building - soil" geotechnical system. Thus, review of literature sources indicates the necessity to study suffusion as a natural fractal. The paper represents the results of experimental research of the soils basing upon innovative methodology that helps predict suffusion deformation by applying fractal theory for the results of determination of microaggregate composition.

Materials and methods. Dispersive loessial soil masses of technogenically built-up territories are in constant dynamic transformation resulting in re-construction of the microstructure and changed physical, physical-mechanical, and hydrogeological properties of those soils. Increased level of ground water, trans- mission of constant and temporal static and dynamic loads, changes in thermal regime result in changing states of soil mass and soil properties both within the zone of complete water saturation and within the aeration zone.

Experimental studies of suffusion effect upon the loessial soils are carried out in terms of loessial soil sample of Dnipro horizon taken within the outcrop of Tunelna ravine erosive system. Geological section of the ravine slope under consideration down to $42.0 \mathrm{~m}$ from the land surface involves Quaternary deposits of loessial complex represented by layering of loamy soils and loamy sands, reddish-brown loamy soils, and underlying Neogene deposits - clays and sands. Ancient and modern landslides are recorded within the right slope of the ravine.

Soils samples under study were taken from the wall of modern landslide disruption and erosivewashed scarp slope. Physical and physical-mechanical characteristics were determined for Black SeaDofinivskyi eolian-deluvial loamy soils (vd PIII $\mathrm{pc}+\mathrm{df}$ ), Bug eolian-deluvial loamy sands (vd P III bg), and Dnipro eolian-deluvial loamy sands (vd P II dn). The soil layers are irregular in their thickness and strike. Within the upper share of the slope, loessial thickness is from 38.8 down to $27.7 \mathrm{~m}$; within the medium share, the thickness is down to $10.6 \mathrm{~m}$; and within the lower share, the thickness is down to 0.0 $\mathrm{m}$. In terms of hydrogeology, one Quaternary waterbearing level located in the loessial deposits of the right ravine slope (vd-e PIII-II pl + kd, vd PII dn, e PII $\mathrm{zv}$ ) is recorded within the right Tunelna ravine slope down to the prospected depth.

Results and discussion. The research involves modeling of the suffusion processes due to long-term filtration involving $10 \%$ solution of $\mathrm{NaCl}$ salt (Fig. 1).

Data concerning changes in the filtration coefficient have been obtained, and calculations of salt content in the solution after the process stabilization have been performed. During the period of 12.02.2018 13.04.2018, sample of Dnipro loessial soil was being 


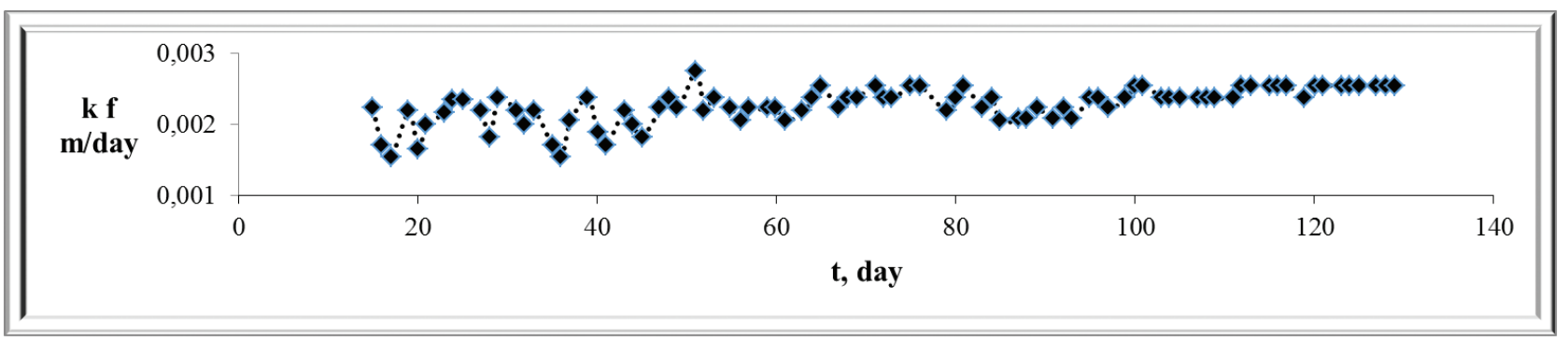

Fig.1. Dynamics of changes in the filtration coefficient according to the experimental results in terms of stable regime.

filtered in Darcy device. Layout and methodology of the research corresponded to the previously completed studies. Liquid volume was measured along with the determination of the filtrate composition in final phase of the experiment when stable regime was obtained (Fig.1). Calculations of the compositions of different. Thus, sample one was subject to mechanical shaking during 2 hours, sample two was prepared with the addition of ammonia solution and boiled during one hour, and sample three was boiled during one hour with the addition of sodium pyrophosphate solution. After that, suspended matter was sampled from

Table 1. Results of chemical analysis of soil samples and filtrates.

\begin{tabular}{|c|c|c|c|c|c|c|c|c|c|c|c|c|c|c|c|}
\hline \multirow{2}{*}{$\begin{array}{l}\dot{\bar{d}} \\
\bar{\Xi} \\
\bar{z}\end{array}$} & \multirow{2}{*}{$\mathrm{pH}$} & \multicolumn{2}{|c|}{$\mathrm{HCO}_{3}^{-}$} & \multicolumn{2}{|c|}{$\mathrm{Mg}^{2+}$} & \multicolumn{2}{|c|}{$\mathrm{Ca}^{2+}$} & \multicolumn{2}{|c|}{$\mathrm{Cl}^{-}$} & \multicolumn{2}{|c|}{$\mathrm{SO}_{4}^{2-}$} & \multicolumn{2}{|c|}{$\mathrm{Na}^{+}+\mathrm{K}^{+}$} & \multirow{2}{*}{$\begin{array}{l}\sum_{\text {ions }}, \\
\mathbf{m g} / \mathbf{1 0 0} \mathbf{g}\end{array}$} & \multirow{2}{*}{$\begin{array}{l}\begin{array}{l}\text { Dry } \\
\text { residue, }\end{array} \\
\mathbf{m g} / \mathbf{1 0 0} \mathbf{g}\end{array}$} \\
\hline & & mg-eq & $\begin{array}{l}\mathrm{mg} / \\
100 \mathrm{~g}\end{array}$ & mg-eq & $\begin{array}{l}\mathrm{mg} / \\
100 \mathrm{~g}\end{array}$ & mg-eq & $\begin{array}{l}\mathrm{mg} / \\
100 \mathrm{~g}\end{array}$ & mg-eq & $\begin{array}{l}\mathrm{mg} / \\
100 \mathrm{~g}\end{array}$ & mg-eq & $\begin{array}{l}\mathrm{mg} / \\
100 \mathrm{~g}\end{array}$ & mg-eq & $\begin{array}{l}\mathrm{mg} / \\
100 \mathrm{~g}\end{array}$ & & \\
\hline 1 & 7.40 & 0.40 & 0.024 & 0.6 & 0.007 & 1.90 & 0.038 & 1.62 & 0.056 & 0.58 & 0.028 & 0.100 & 0.002 & 0.143 & 0.147 \\
\hline 2 & 7.42 & 0.63 & 0.038 & 6.06 & 0.074 & 12.62 & 0.252 & 16.27 & 0.577 & 18.38 & 0.882 & 16.60 & 0.382 & 2.186 & 2.192 \\
\hline 3 & 7.75 & 0.77 & 0.047 & 5.97 & 0.073 & 28.98 & 0.580 & 29.42 & 1.043 & 20.24 & 0.972 & 15.48 & 0.356 & 3.048 & 3.050 \\
\hline 4 & 7.84 & 0.51 & 0.031 & 1.67 & 0.020 & 7.34 & 0.147 & 15.58 & 0.552 & 3.29 & 0.158 & 10.37 & 0.239 & 1.132 & 1.134 \\
\hline
\end{tabular}

Table 2. Calculation of hypothetic salts.

\begin{tabular}{|c|c|c|c|c|c|c|c|c|c|c|c|c|c|c|}
\hline \multirow[b]{2}{*}{ Number } & \multicolumn{2}{|c|}{$\mathrm{Ca}\left(\mathrm{HCO}_{3}\right)_{2}$} & \multicolumn{2}{|c|}{$\mathrm{CaSO}_{4}$} & \multicolumn{2}{|c|}{$\mathrm{MgSO}_{4}$} & \multicolumn{2}{|c|}{$\mathrm{Na}_{2} \mathrm{SO}_{4}$} & \multicolumn{2}{|c|}{$\mathrm{NaCl}$} & \multicolumn{2}{|c|}{$\mathrm{CaCl}_{2}$} & \multicolumn{2}{|c|}{$\mathrm{MgCl}_{2}$} \\
\hline & mg-eq & $\%$ & mg-eq & $\%$ & mg-eq & $\%$ & mg-eq & $\%$ & mg-eq & $\%$ & mg-eq & $\%$ & mg-eq & $\%$ \\
\hline 1 & 0.80 & 15.38 & 1.16 & 22.31 & - & - & - & - & 0.2 & 3.85 & 1.84 & 35.38 & 1.2 & 23.08 \\
\hline 2 & 1.26 & 1.79 & 23.98 & 33.98 & 12.12 & 17.18 & 0.66 & 0.94 & 32.54 & 46.11 & - & - & - & - \\
\hline 3 & 1.54 & 1.53 & 40.48 & 40.13 & - & - & - & - & 30.96 & 30.70 & 15.94 & 15.80 & 11.94 & 11.84 \\
\hline 4 & 1.02 & 2.63 & 6.58 & 16.98 & - & - & - & - & 20.74 & 53.51 & 7.08 & 18.27 & 3.34 & 8.61 \\
\hline
\end{tabular}

hypothetic salts are represented below (Tables 1,2).

Objective of the study was to determine changes in granulometric composition of the loessial soil sample due to long-term salt solution filtration. That process models the effect upon granulometric composition of chemical and mechanical suffusion. To study suffusion process within the loessial soil, microaggregate and granulometric composition of the regularstructure sample of Dnipro loessial horizon sampled within Tonelna ravine outcrop has been analyzed.

Algorithm of microaggregate study according to the methodology (Riashchenko, 2010) is as follows: the sample experiences different methods of preparation so that evaluations of soil dispersion would be the depths of 25,10 , and $7 \mathrm{~cm}$ (in an hour interval) being determined by the standard and depending upon the temperature. Mass value of the average sample is used to define quantitative fraction content according to formula:

$$
\mathrm{X}=\mathrm{A} * 1000 *(100-\mathrm{K}) /\left(\mathrm{g}_{0} * \mathrm{~V}_{\mathrm{n}}\right)
$$

where, A - is mass of soil fraction within the sample of the known volume brought to the constant mass value, $\mathrm{g}$;

$\mathrm{g}_{0}$ - is mass of absolute dry soil sample, initial value, $\mathrm{g}$; $\mathrm{V}_{\mathrm{n}}$ - is pipette capacity, $\mathrm{cm}^{3}$;

$K^{n}-$ is total content of soil fraction of the size more 
than $1 \mathrm{~mm}, \%$.

Results of the study of microaggregate composition of the sample being subject to long-term salt solution filtration have made it possible to determine certain changes in microaggregate soil composition. Percentage content of the particles according to the have been defined. The obtained results have made it possible to develop cumulative curves of granulometric composition of the samples having been prepared by three different methods. Those curves show the difference between the content of the particles of 0.1 0.05 and $0.05-0.01 \mathrm{~mm}$ depending upon the method

Table 3. Percentage content of fraction particles.

\begin{tabular}{|l|l|l|l|l|l|l|}
\hline \multirow{2}{*}{$\begin{array}{l}\text { Method of sample } \\
\text { preparation }\end{array}$} & \multicolumn{5}{|c|}{ Percentage content of particles of the indicated fraction, mm } \\
\cline { 2 - 7 } & $0.1-0.05$ & $0.05-0.01$ & $0.01-0.005$ & $0.005-0.002$ & $0.002-0.001$ & $\begin{array}{l}\text { less than } \\
0.001\end{array}$ \\
\hline Aggregate & 43.353 & 21.763 & 31.433 & 0.000 & 2.713 & 3.274 \\
\hline Semi-disperse & 33.580 & 64.053 & 0.000 & 2.037 & 3.030 & 0.095 \\
\hline Disperse & 77.944 & 15.169 & 0.000 & 4.393 & 9.431 & 2.047 \\
\hline
\end{tabular}

study results is represented below (Table 3).

Basing upon the obtained results, coefficient values of microaggregation have been calculated; data on the amount of aggregates and initial particles have been obtained. It has been determined that the aggregates size is mostly $0.01-0.005 \mathrm{~mm}$; aggregates of $0.05-0.01 \mathrm{~mm}$ are found less often; and finefraction aggregates demonstrate the least amount. That indicates certain changes in microaggregate soil composition due to the carrying out of fine fractions and the disturbances of larger aggregates. Content of the initial particles and content of the particles in microaggregates of the corresponding fractions have of sample preparation (Fig 2).

According to the methodology (Mokrytska, Tushev et al., 2018), values of fractal size of the functions of particle distribution in terms of their mass have been calculated (Fig.3). Values of the determination coefficient of linear trend equations indicate considerable importance of the obtained equations. Value of angle coefficient shows the effect of the preparation method upon the value of fractal size of the function of particles distribution in terms of their mass.

Next stage involves calculation of the porosity coefficient value of soil in terms of complete decay

Table 4. Percentage content of the initial particles

\begin{tabular}{|c|c|c|c|c|c|c|c|c|c|c|c|c|}
\hline Parameter & M1 & M1-a & M2 & M2-a & M3 & M3-a & M4 & M4-a & M5 & M5-a & M6 & M6-a \\
\hline Percentage content of particles, $\%$ & 43,353 & 34,591 & 15,169 & - & - & - & - & 4,393 & 2,713 & 6,717 & 2,047 & - \\
\hline Fraction size, mm & $\begin{array}{l}0,1- \\
0,05\end{array}$ & & $\begin{array}{c}0,05- \\
0,01\end{array}$ & & $\begin{array}{l}0,01- \\
0,005\end{array}$ & & $\begin{array}{c}0,005- \\
0,002\end{array}$ & & $\begin{array}{c}0,002- \\
0,001\end{array}$ & & $\begin{array}{c}\text { Less } \\
0,001\end{array}$ & \\
\hline
\end{tabular}

Note for Table 4:

M1 - content of the initial particles;

M1-a - content of the particles in aggregates.

Table 5. Results of the calculation of forecast values of the porosity coefficient

\begin{tabular}{|l|c|c|c|}
\hline $\begin{array}{l}\text { Method of sample } \\
\text { preparation for the } \\
\text { analysis }\end{array}$ & $\begin{array}{l}\text { Value of fractal size of the } \\
\text { function of particles distribu- } \\
\text { tion in terms of their mass D }\end{array}$ & $\begin{array}{l}\text { Claculation } \\
\text { coefficient value }\end{array}$ & $\begin{array}{l}\text { Forecast value of the } \\
\text { porosity coefficient } \mathbf{k}\end{array}$ \\
\hline Aggregate & 0.189 & 0.738 & 0.961 \\
\hline Disperse & 0.071 & 0.892 & 0.668 \\
\hline Semi-disperse & 0.212 & 0.711 & 1.019 \\
\hline
\end{tabular}

been calculated (Table 4).

No availability of the initial particles of fine argillaceous composition and general decrease in the amount of fine particles comparing to the natural state of samples microaggregates having experienced mechanical or chemical action of different degree (Table 5). Those values are the forecast ones indicating porosity value of the soil medium having experienced 


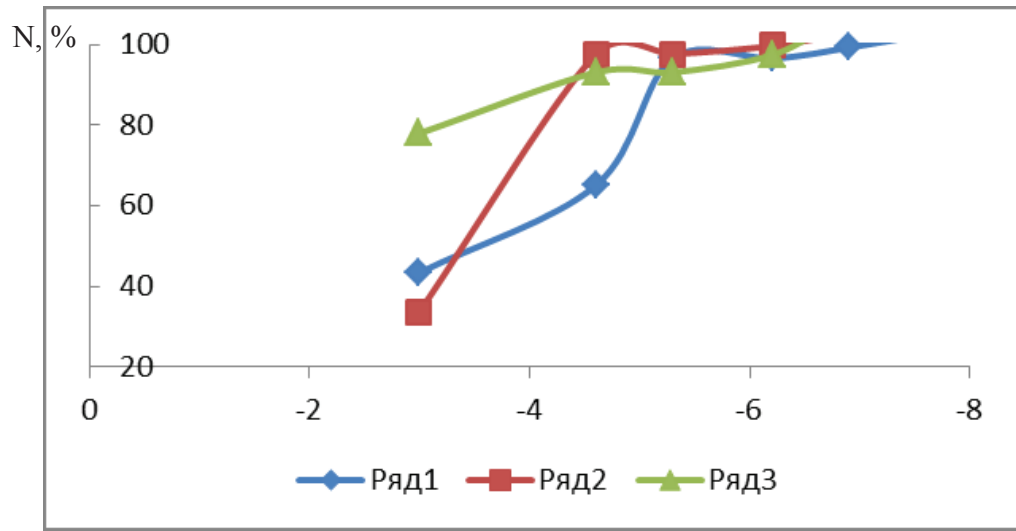

Fig. 2. Cumulative curves of granulometric composition of the sample of Dnipro loessial horizon having been subject to long-term salt solution filtration

Notes for Fig. 2:

$\mathrm{N}, \%$ - total number of particles;

$\ln \mathrm{R}$ - logarithm of particle size;

Row 1 - aggregate method of sample preparation (mechanical shaking during 2 hours);

Row 2 - semi-disperse method of sample preparation (with the addition of ammonia solution);

Row 3 - disperse method of sample preparation (with the addition of sodium pyrophosphate solution).

Table 6. Forecast values of the deformation of the sample of Dnipro loessial horizon.

\begin{tabular}{|c|c|c|c|c|}
\hline \multicolumn{5}{|c|}{ Results of calculation of forecast deformation of the sample } \\
of Dnipro loessial horizon vdP II dn \\
$\begin{array}{c}\text { Method of sample } \\
\text { preparation } \\
\text { function of particles distri- } \\
\text { bution in terms of their mass }\end{array}$ & $\begin{array}{c}\text { Vorosity coefficient } \\
\text { of a natural-state } \\
\text { sample }\end{array}$ & $\begin{array}{c}\text { Porosity coefficient } \\
\text { of a changed-state } \\
\text { sample }\end{array}$ & $\begin{array}{c}\text { Volumetric } \\
\text { sample defor- } \\
\text { mation }\end{array}$ \\
\hline $\begin{array}{c}\text { Aggregate prepara- } \\
\text { tion }\end{array}$ & 2.669 & 0.706 & 0.74 & -0.034 \\
\hline $\begin{array}{c}\text { Preparation with } \\
\text { magnetic shaker }\end{array}$ & 2.706 & 0.718 & 0.741 & -0.023 \\
\hline $\begin{array}{c}\text { Preparation as long- } \\
\text { term water solution } \\
\text { filtration }\end{array}$ & 2.605 & 0.711 & 0.737 & -0.027 \\
\hline
\end{tabular}

Table 7. Forecast deformation values due to salt solution filtration

\begin{tabular}{|c|c|c|c|}
\hline $\begin{array}{c}\text { Method of soil prepa- } \\
\text { ration }\end{array}$ & $\begin{array}{c}\text { Porosity coefficient of a } \\
\text { natural-state sample }\end{array}$ & $\begin{array}{c}\text { Porosity coefficient of a } \\
\text { changed-state sample }\end{array}$ & $\begin{array}{c}\text { Volumetric sample } \\
\text { deformation }\end{array}$ \\
\hline Aggregate preparation & \multirow{2}{*}{0.711} & 0.96 & -0.249 \\
\hline $\begin{array}{c}\text { Semi-disperse prepara- } \\
\text { tion }\end{array}$ & & 1.019 & -0.308 \\
\hline Disperse preparation & & 0.668 & 0.04 \\
\hline
\end{tabular}

long-term salt solution filtration and mechanical or chemical effect resulting in complete decay of all the microaggregates.

Comparison of the obtained values with the porosity coefficient values of natural-state soil (Table 5) and changed soil (Table 7) demonstrates the expected consequences of the effect of suffusion process upon the porosity of Dnipro loessial horizon sample.

While analyzing the data, it should be noted that disturbance of microaggregates results in the formation of looser structure; in this context, filtration is less important factor than the action of magnetic field or mechanical shaking. 


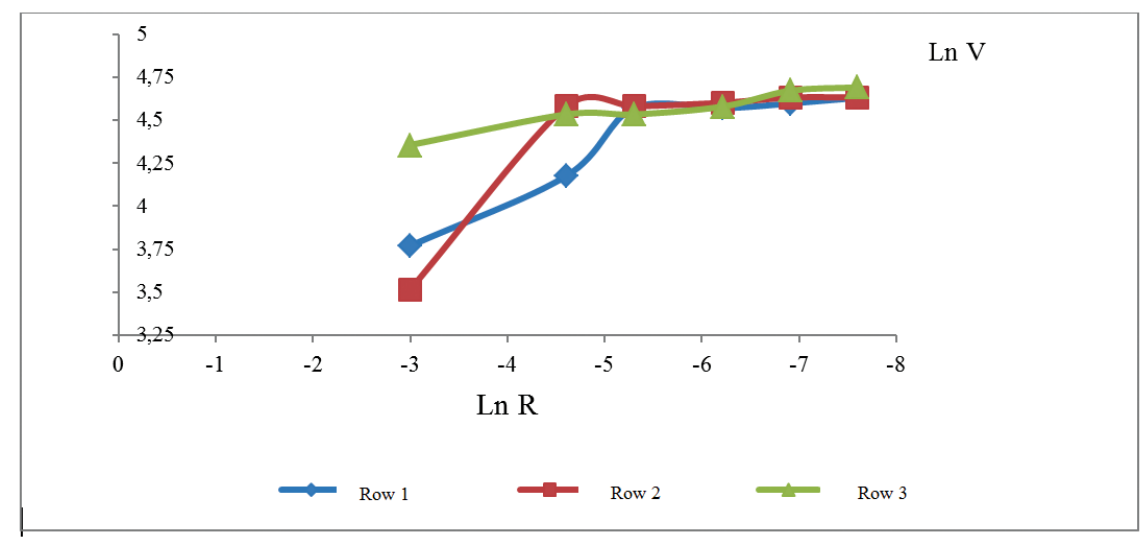

Fig.3. Graphs of the dependence of logarithm of particle distribution function in terms of the mass upon the logarithm of particle sizes.

Note for Fig. 3:

Ln V, \% - total volume of particles;

Ln R - logarithm of particle size;

Row 1 - aggregate method of sample preparation;

Row 2 - disperse method of sample preparation;

Row 3 -semi-disperse method of sample preparation.

According to the results of previous studies due to filtration with water solution, increased coefficient of soil porosity should be expected. Calculations of the values of soil volumetric deformation due to long-term filtration with salt solution show the fact that possible microaggregates decay within the zones of technogenic contamination due to chemical effect will result in the formation of structure with denser particles packing, i.e. compaction.

If loessial horizons with the changed state due to salt solution filtration are subject to mechanical effect, there is possible soil loosening (even, drastic loosening) and loss of soil stability.

Thus, comparison of the results shows considerable changes in the soil state due to suffusion within the zones of technogenic contamination. Certain regularities of changes in soil porosity in the state of complete degradation in terms of complete decay of microaggregates due to mechanical suffusion or processes of solution and carrying out of particles during salt solution filtration have been defined. It has been demonstrated that density deformation is possible only in the context of disperse preparation in terms of maximum decay of microaggregates.

Conclusions and their discussion. The paper represents the results of long-term experiment on determining regularities of changes in loessial soil state within the zones of technogenic action.

Effect of chemical composition of the solution upon the regularities of changes in granulometric and microaggregate soil composition has been confirmed.

It has been proved that suffusion may result in loss of soil strength and compaction.

For the first time, forecast values of the porosity coefficient of loessial Dnipro horizon have been obtained; the values will correspond to new soil state.

For the first time, the experimental results have made it possible to prove the possibility to obtain forecast values of the properties of the medium experiencing certain changes due to suffusion.

\section{References}

Gudehus G., Touplikiotis A., 2018. On the stability of geotechnical systems and its fractal progressive loss Acta Geotech. 13: 317 . https://doi. org/10.1007/s11440-017-0549-x

Ziani H., Abbèche, K., Messaoudene, I. et al., 2019. KSCE, J Civ Eng 23: 1028. https://doi.org/10.1007/ s12205-019-0051-0

Jafari F. K., Asgari M. S., Pishkoo A. The Fractal Calculus for Fractal Materials, 2019. Fractal Fract, 3(1), 8; https://doi.org/10.3390/fractalfract3010008

Khuzhaerov B. J., 1994. A model of multicomponent grouting and suffosion filtration Eng Phys Thermophys, Vol. 66, Issue 4, pp. 373-379. https://doi.org/10.1007/BF00853459

Liu Y., Gong Y., Wang X. et al., 2013. Volume fractal dimension of soil particles and relationships with soil physical-chemical properties and plant species diversity in an alpine grassland under different disturbance degrees Arid Land 5: 480. https://doi.org/10.1007/s40333-013-0184-9

Lu S., Tang, H., Zhang, Y. et al., 2018. Bull Effects of the particle-size distribution on the micro and macro behavior of soils: fractal dimension as an indicator of the spatial variability of a slip zone in 
a landslide Eng Geol Environ 77: 665. https://doi. org/10.1007/s10064-017-1028-1

Mokritskaya T.P., , Tushev A.V., Samoylich K.A. et al., 2019. Bull Eng Geol Environ 78: 3729. https:// doi.org/10.1007/s10064-018-1361-z

Nikiforov A.I., , 2000. J Modeling of suffosion of waterbearing strata Eng Phys Thermophys 73: 959. Vol. 73, Issue 5, pp. 959-965 https://doi.org/10.1007/ BF02681587

Wang G. L. J., Xuan L., Xinhui L., Xiaosai L., Yaqiong R., Jing W., 2018. Liming Dong Partitioning and geochemical fractions of heavy metals from geogenic and anthropogenic sources in various soil particle size fractions. Geoderma,Vol. 312, 15 February, Pages 104-113. https://doi. org/10.1016/j.geoderma.2017.10.013

Wang J., Zhang M., Bai Z. et al., 2015. Multi-fractal characteristics of the particle distribution of reconstructed soils and the relationship between soil properties and multi-fractal parameters in an opencast coal-mine dump in a loess area. Environ Earth Sci 73: 4749. https://doi.org/10.1007/ s12665-014-3761-0 